See discussions, stats, and author profiles for this publication at: https://www.researchgate.net/publication/341171661

\title{
Spanish version of the Status Anxiety Scale (Versión española de la Escala de Ansiedad por el Estatus)
}

Article in Revista de Psicología Social · April 2020

DOI: $10.1080 / 02134748.2020 .1721050$

\section{CITATIONS}

5 authors, including:

Davide Melita

University of Granada

3 PUBLICATIONS 7 CITATIONS

SEE PROFILE

David Iruela

Universidad de Buenos Aires

2 PUBLICATIONS 7 CITATIONS

SEE PROFILE
READS

344

A. Andrea Velandia-Morales

University of Granada

31 PUBLICATIONS 176 CITATIONS

SEE PROFILE

(79) Guillermo B. Willis

University of Granada

84 PUBLICATIONS 595 CITATIONS

SEE PROFILE

Some of the authors of this publication are also working on these related projects:

Consequences of Animalizing the Poor and Mechanizing the Wealthy in the Maintenance of Socioeconomic Differences View project

Effects of perceived inequality on Status Anxiety View project 
Status Anxiety Scale: Spanish version / Escala de Ansiedad por el Estatus: versión

española

\title{
Spanish version of the Status Anxiety Scale (Versión española de la Escala de Ansiedad por el Estatus)
}

Davide Melita, Andrea Velandia-Morales, David Iruela-Toros, Guillermo B. Willis and

Rosa Rodríguez-Bailón

Universidad de Granada

(Received 2 August 2019, accepted 9 November 2019)

\begin{abstract}
This study presents the adaptation and evidence of validity of the Spanish version of the Status Anxiety Scale. This measure evaluates people's tendency to be concerned with their socioeconomic status. In two correlational studies, one exploratory $(N=270)$ and one confirmatory $(N=258)$, the instrument showed good reliability, in addition to a one-factor structure and a positive correlation with relative deprivation, tendency towards social comparison and perception of inequality. Furthermore, a third experimental study $(N=140)$ found that the participants in the condition of low socioeconomic status experienced greater status anxiety. In short, these studies suggest that the Spanish version of the Status Anxiety Scale can be used in the Spanish population.
\end{abstract}

\section{Keywords}

status anxiety, socioeconomic status, inequality, relative deprivation.

\section{Resumen}

En este trabajo se presenta la adaptación y las evidencias de validez de la versión española de la Escala de Ansiedad por el Estatus. Esta medida evalúa la tendencia de las personas a preocuparse por su posición socioeconómica. En dos estudios correlacionales, de corte exploratorio $(N=270)$ y confirmatorio $(N=258)$, el instrumento mostró una buena fiabilidad, además de una estructura unifactorial y correlaciones positivas con privación relativa, tendencia a la comparación social, y percepción de desigualdad. Además, en un tercer estudio experimental $(N=140)$, se encontró que en la condición de bajo estatus socioeconómico los/as participantes experimentaron mayor ansiedad por el estatus. En suma, estos estudios sugieren que la Versión Española de la Escala de Ansiedad por el Estatus puede ser utilizada en población española.

\section{Palabras clave}

ansiedad por el estatus, estatus socioeconómico, desigualdad, privación relativa.

Translation from Spanish/ Traducción del español: Mary Black

CONTACT Davide Melita, Departamento de Psicología Social, Universidad de Granada. Centro de Investigación Mente, Cerebro y Comportamiento (CIMCYC).

Campus Cartuja s/n, 18071 Granada, España. E-mail: dmelita@ugr.es

Note: this is a preprint version of the manuscript to be published in Revista de Psicología Social 
The inhabitants of the Spanish city with the lowest per capita income (Sanlúcar de Barrameda) live an average of 5 years less than the inhabitants of the city with the highest per capita income (Pozuelo de Alarcón) (INE, 2019). This difference is due not only to the material living conditions, since beyond income, a person's socioeconomic status determines their health and life expectancy (Marmot, 2004a). Given that today's societies are increasingly unequal and hierarchised (Piketty, 2013), socioeconomic differences are becoming increasingly important (Wilkinson \& Pickett, 2009). In highly hierarchised contexts, (i.e., in human and non-human primate hierarchies), occupying low-status positions can even lead to changes in metabolism and the immune system, which increase the risk of chronic disease like diabetes and heart disease (De Vogli, Ferrie, Chandala, Kivimäki, \& Marmot, 2006; Marmot, 2004b).

Just like other mammals, human beings are aware of social hierarchies and individuals' positions within them. For example, it has been found that people are quickly able to identify the socioeconomic status of strangers with very little information about them (Kraus, Park, \& Tan, 2017). The desire to maintain status in a hierarchy or to achieve a higher status is a motivation which can be considered part of our evolutionary inheritance (Anderson, Hildreth, \& Howland, 2015). However, today economic differences have turned the desire for status into a constant concern (De Botton, 2004) which can cause stress reactions or interfere in people's lives (Gruenewald, Kemeny, \& Aziz, 2006).

Experiencing status anxiety (SA) leads people at any social status to constantly worry about not reaching the standards of success in society, being stuck in their social standing or losing their status (De Botton, 2004; Paskov, Gërxhani, \& van de Werfhorst, 2013). SA may lead to more selfish and less socially conscious behaviours (Paskov et al., 2013), as well as discrimination against those who are on lower rungs of the social 
ladder (De Botton, 2004; Liu, Soleck, Hopps, Dunston, \& Pickett, 2004). A very general measure based on a single item has frequently been used in international studies to measure the experience of SA (i.e. "Some people look down on me because of my job situation or income"; Delhey \& Dragalov, 2014; Layte \& Whelan, 2014). However, the use of a single item to measure complex psychological constructs has been criticised for being limited in terms of the applicability of content validity criteria and the difficulty proving its reliability (Fisher, Matthews, \& Gibbons, 2016). Recently, Day and Fiske (2016) developed a brief English-language Status Anxiety Scale capable of measuring this construct with sound reliability and validity indicators. In this study, we present different evidence of validity and reliability of this instrument in Spanish.

\section{Status anxiety}

People experience stress responses when faced with the possibility of losing status (Scheepers, Ellemers, \& Sintemaartensdijk, 2009) or not reaching the standards of socioeconomic success in their milieu (De Botton, 2004). The concern with one's own status leads people to react negatively when they perceive that they are being evaluated and therefore their self-image may be threatened (Gruenewald, Kemeny, \& Aziz, 2006). In clinical practice, the concern with one's socioeconomic status has been proposed as the root of certain emotional disorders, low performance or failure at school or work (Liu, Soleck, Hopps, Dunston, \& Pickett, 2004). The negative relationship between SA and mental health reveals the importance of evaluating SA as a potential mental health risk factor and the need to have appropriate instruments to measure it (Layte, 2012).

SA is also a frequent construct when analysing the psychosocial effects of economic inequality. In fact, several theoretical models have posited that some of the negative consequences of living in a more unequal society (e.g., higher frequency of 
risky behaviours, increase in debt, increase in competitiveness and decrease in subjective wellbeing) are partly due to the SA generated in these contexts (Buttrick \& Oishi, 2017; Loughnan et al., 2011; Paskov et al., 2013; Wilkinson \& Pickett, 2009; 2017). Similarly, studies using international surveys have found that SA explains the negative relationship between economic inequality and different indicators of wellbeing and health (Delhey \& Dragalov, 2013; Layte, 2012).

Likewise, it is important to establish that SA is a distinct construct than others cited in the literature. For example, although it describes people's tendency to be concerned with and perceive situations as threatening, it differs from trait-anxiety (Balsamo et al., 2013) because its subject of concern is more specific than in traitanxiety. In status anxiety, the concern is with socioeconomic status as a reaction to the social organisation that organises the society in which the person lives (Solak, Jost, Sümer, \& Clore, 2012). It also differs from other related constructs like materialism (Richins \& Dawson, 1992), status-seeking (Paskov et al, 2017) and a concern with status (Kaufman, 1957) since it refers not to people's value systems (i.e., to what extent people consider economic success an important value) but to the society in general in which the individuals live (De Botton, 2004).

Alderson and Katz-Gerro (2016) found that the importance people attribute to comparing their income with others' income negatively affects their subjective wellbeing beyond their income. This tendency towards social comparison may be higher among those who assign more importance to economic success (Kim, Callan, Gheorghiu, \& Matthews, 2017), status and status-seeking (Alba, McIlwain, Wheeler, \& Jones, 2014). Previous studies have found that SA leads people to constantly compare themselves with those with higher socioeconomic status, thus increasingly the likelihood of experiencing relative deprivation (Paskov et al., 2013). Furthermore, 
unequal societies have been found to lead to a higher consumption of goods to signal status due to people's greater concern with their status within the social hierarchy (Walasek \& Brown, 2015). Ultimately, people with higher levels of public selfconsciousness, that is, those concerned with their image in others' eyes, are characterised by being highly vigilant of others' assessments (Scheier \& Carver, 1985). Socioeconomic status is an attribute granted by others (Prinstein, 2017) which is often associated with an assessment of the person (De Botton, 2004; Paskov et al., 2017), so public self-consciousness and SA may be related.

\section{Development of the Spanish version of the Status Anxiety Scale}

In order to have a version of the Status Anxiety Scale which is translated and adapted and shows evidence of validity in Spain, two studies with independent samples were conducted. Previously, the original English-language items of the Status Anxiety Scale (Day \& Fiske, 1996) were subjected to an inverse translation process and expert judgement in its Spanish version (Delgado-Rico, Carretero-Dios, \& Ruch, 2012; Hambleton, 2005). The resulting scale, which is comprised of five items, was administered to a sample with the goal of exploring its psychometric characteristics and factor structure. In the second study, the factor structure was confirmed by administering the scale to another independent sample from the general population. Evidence of the scale's reliability and validity were also obtained in both studies. Finally, a third experimental study was conducted to provide evidence of the causal relationship between socioeconomic status and SA.

\section{Study 1}

In order to analyse the psychometric properties and explore the factor structure of the Spanish version of the Status Anxiety Scale, an initial study was conducted which also, 
for the first time, provided evidence of the scale's convergent validity when analysing its expected relationship with other measures. Specifically, this study examined whether the participants who experienced higher SA also reported higher: a) relative deprivation (Hypothesis 1); b) status-seeking levels (Hypothesis 2); c) tendency to compare (Hypothesis 3) and d) public self-consciousness (Hypothesis 4).

Furthermore, because of its possible relevance to the SA construct, the first study explored the relationships between SA and perceived economic inequality, tolerance of economic inequality and socioeconomic status, and other measures were also included for exploratory purposes. All the measures included in the exploratory questionnaire, the analyses and the results are available on OSF (https://osf.io/7v2wf/).

\section{Method}

The items on the original Status Anxiety Scale were subjected to an inverse translation, and any discrepancies between the two English versions were analysed and resolved through the criterion of maximum semantic fidelity to the original version of the scale (Hambleton, 2005). After that, the Spanish version of the items was subjected to expert judgement (Delgado-Rico, Carretero-Dios, \& Ruch, 2012). Specifically, five social psychology researchers evaluated each item on the scale on the dimensions of representativeness, comprehensibility, ambiguity and conciseness. The judges evaluated all the items in these dimensions using a 4-point Likert scale. In this expert judgement, the order of the items was randomised, and one item extracted from the Spanish version of the Generalised Sense of Power Scale (Willis, Carretero-Dios, Rodríguez-Bailón, \& Petkanopoulou, 2016) was included to check the discriminatory validity of the expert judges in relation to the dimension of representativeness of the construct. This item obtained a Content Validity Index $(\mathrm{CVI})=0($ Kappa inter-judge agreement index $=1)$ indicating that the experts properly discriminated the representativeness of the items. 
The scale showed appropriate representativeness values (CVI $=.88$ and Kappa interjudge agreement index $=.76$ ). Considering the observations of the judges, minimal changes were made to four of the five items in order to improve their comprehensibility and lower their ambiguity. Appendix 1 shows the final version of the scale.

Participants. A total of 276 people (55\% females, $34 \%$ males, $11 \%$ sex not indicated) between the ages of 18 and $76(M=30.74 S D=14.22)$ participated in the first study. The data from six of these people were excluded from the analysis because they were not Spanish nationals; $35.8 \%$ of the participants belonged to the first quartile in the distribution of Mean Household Disposable Income (MHDI) of the Spanish population $^{1}$ (less than $€ 1,426$ per month in a household of 2 adults and one child under the age of 14), while $29 \%$ belonged to the second quartile (between $€ 1,426$ and $€ 2,218$ ), $20.7 \%$ to the third quartile (between $€ 2,218$ and $€ 3,248$ ) and $14.5 \%$ to the last quartile (more than $€ 3,248$ per month). However, $30.1 \%$ of the participants did not indicate their household income.

\section{Instruments}

Spanish version of the Status Anxiety Scale (Appendix 1).

Relative Deprivation. A single item was used ("In the past five years, how would you say you have fared economically compared to other people like you?"), with a 5-point response scale (1, "much better" to 5, "much worse"). This item measures individual relative deprivation (Pettigrew \& Meertens, 1995; Vanneman \& Pettigrew, 1972).

Status-seeking. The Status Consumption Scale (Kilsheimer, 1993) was used. It includes five items (e.g. "I would buy a product because it gives me status"), and it uses a Likert response scale from 1 (totally disagree) to 5 (totally agree). The reliability of 
the scale was adequate $(\alpha=.75)$; however, the participants' responses were clustered at the lower end of the scale $(M=1.64 S D=0.74)$.

Social Comparison. The INCOM-E scale (Buunk, Belmont, Peiró, Zurriaga, \& Gibbons, 2005) was used, which is comprised of 11 items which measure people's tendency to compare themselves with others (e.g. "I often compare myself with others in terms of what I have achieved in life"), with a Likert response scale from 1 (totally disagree) to 5 (totally agree). The reliability of the scale was adequate ( $\alpha=.82 ; M=$ $2.96 S D=0.72)$.

Public Self-Consciousness. The public self-consciousness subscale of the SelfConsciousness Scale was used, after it was adapted to and validated in the Spanish population (López-Bonilla \& López-Bonilla, 2010; Scheier \& Carver, 1985). This scale is comprised of seven items (e.g. "I'm interested in what others think of me"). It uses a Likert response scale from 1 (totally disagree) to 5 (totally agree). The reliability of the scale was adequate $(\alpha=.78 ; M=3.44 S D=0.76)$.

Subjective Socioeconomic Status (SSS). The MacArthur Scale (Adler, 2001) was used. On a scale of 1 to 10 , the participants indicated where they would situate themselves compared to the rest of Spanish society today in terms of their resources, money, education and work.

Objective Socioeconomic Status (OSS). The income decile according to the MHDI was calculated for each participant using data from Eurostat (http://ec.europa.eu/8urostat/data/database).

Perceived Inequality. Two items were used to ask the participants about their general perception of economic inequality (e.g., "To what extent do you believe that Spanish society today is unequal (or egalitarian) in the distribution of economic 
resources?"). The mean of both was used as an indicator of perceived economic inequality $(r=.45, p<.001)$.

Tolerance of Inequality. One item was used which has traditionally been used in previous studies (García-Sánchez, Van der Toorn, Rodríguez-Bailón, \& Willis, 2018) and is included in the International Social Survey ("The income differences in Spain are too great").

\section{Procedure}

A survey was conducted by incidental sampling at the bus station in the capital city of a province in Andalusia, Spain. After reading and accepting an informed consent document, each participant individually answered the items on the questionnaire anonymously and confidentially in approximately 15 minutes. In addition to the measures described above, the questionnaire also contained several scales unrelated to this study (available at https://osf.io/7v2wf/). All the studies included in this article were approved by the ethics committee of the university with which the lead authors are affiliated.

\section{Results}

The items showed discrimination indexes (indicated by the item's correlation to the corrected total) of between .60 and .81 , and a good ability to capture the participants' variations in the construct measured $\left(S D_{\text {all items }}>1\right)$. The mean of the scale was close to the midpoint $(M=4.19 ; S D=1.55)$.

The result of the Bartlett sphericity text $\left(\chi^{2}=599.18 ; p<.001\right)$ and the KMO index (.84) indicated the suitability of the correlation matrix for the exploratory factor analysis of the scale through the extraction of principal components. 
The exploratory factor analysis revealed a single factor with an eigenvalue higher than 1 which explains $65 \%$ of the variance. The saturations of the items in this factor ranged between .74 and .89 .

The scale showed good internal consistency $(\alpha=.86)$, and, as shown in Table 1, it showed evidence of convergent validity when related to all the hypothesised variables. It was only not related to the status-seeking measure through status consumption. This may be due to the fact that the scores on this scale were extremely low $(M=1.65 ; S D=0.74)$, perhaps due to social desirability and therefore there may have been a "ground" effect in their scores.

[TABLE 1]

\section{Exploratory analyses}

SA was positively related to perception of inequality $(r=.32 ; p<.001,95 \% \mathrm{CI}$ $[0.21,0.42])$ and to intolerance of inequality ("The income differences in Spain are too great"; $r=.22 ; p<.001,95 \% \mathrm{CI}[0.11,0.33])$, and was negatively related to SSS $(r=-$ $.38 ; p<.001,95 \%$ CI $[-0.49,-0.28])$ and OSS $(r=-.27 ; p<.001,95 \%$ CI $[-0.39,-$ 0.13]). People with low status experienced the highest SA.

\section{Discussion}

This study provided evidence of the one-factor structure of the scale. Likewise, it found that the scale showed adequate reliability, and evidence of the scale's convergent validity was found as it is positively related to the constructs of relative deprivation, social comparison and public self-consciousness. Different exploratory analyses also found that it was negatively related to socioeconomic status and positively related to the perception and (in)tolerance of inequality. The Spanish version of the Status Anxiety 
Scale is therefore an instrument with sound reliability indices and shows relations with relevant constructs for studying the causes and consequences of SA.

\section{Study 2}

Following the same procedure as in Study 1, a second study was conducted with the goal of confirming the one-factor structure of the Status Anxiety Scale and providing further evidence of its validity. Study 1, which was exploratory, found that SA was positively related to perceived inequality and negatively related to socioeconomic status. This result may be due to the fact that economic inequality increases the social distance among people occupying different positions within the social hierarchy (Wilkinson \& Pickett, 2009), which leads individuals to be concerned with the social position they occupy and want to achieve. SA may partly explain some of the psychosocial effects of economic inequality (Paskov et al., 2013), so we set out to replicate these results in Study 2. Therefore, we predicted that: a) SA would be positively related to perceived inequality (Hypothesis 5) and b) negatively related to subjective status social (SSS) and objective socioeconomic status (OSS), indicated by the income decile (Hypotheses 6a and 6b).

In the Study 2, we also set out to replicate the result obtained in Study 1 in relation to Hypothesis 1, namely that SA is positively associated with relative deprivation.

This second study included measures from other constructs that are theoretically related to SA for exploratory purposes, as well as other measures not included in this study. These measures, analyses and results are available on OSF (https://osf.io/jbdhq/).

\section{Method}


Participants. A total of 269 people (53\% females, 33\% males, $14 \%$ sex not indicated $)$ between the ages of 18 and $73(M=30.88, S D=13.93)$ participated in this study; $38.5 \%$ belonged to the first income quartile, $25.1 \%$ to the second quartile, $17.6 \%$ to the third quartile and $18.7 \%$ to the last quartile, while $30.5 \%$ of the participants did not indicate their household income.

The data on 11 people were excluded from the analysis because they were not Spanish nationals.

Instruments. Just as in Study 1, the Spanish version of the Status Anxiety Scale and the same measures of relative deprivation, perceived inequality, SSS and OSS used previously were also included in this second study.

\section{Results}

Given that the theoretical definition of the construct implies a one-dimensional scale structure and that the exploratory factor analysis in Study 1 revealed a single factor, a confirmatory factor analysis was conducted through a robust maximum likelihood estimator, and the model's fit was determined by jointly evaluating the Root Mean Square Error of Approximation (RMSEA), Standardised Root Mean Square Residual (SRMR) and Comparative Fit Index (CFI) (Kaplan, 2000). These fit measures indicated an acceptable one-dimensional model $(R M S E A=.00, S R M R=.01, C F I=1)$. The single factor of the scale also showed good reliability $(\alpha=.87)$.

Table 2 shows the correlations of the Spanish version of the Status Anxiety Scale with the measures on relative deprivation, perceived inequality, SSS and OSS. The results of Study 1 in relation to Hypothesis 1 were replicated by finding a positive relationship between SA and relative deprivation. 
Evidence of validity was once again provided by the positive correlation between SA and perceived inequality, as predicted in Hypothesis 5, and by the negative correlation between SA and SSS and OSS, as predicted in Hypothesis 6.

[TABLE 2]

\section{Discussion}

In Study 1, we found evidence of both the reliability of the Spanish version of the Status Anxiety Scale and its one-factor structure. This second study confirmed the scale's onefactor structure because the single-factor model showed adequate fit in the confirmatory factor analysis undertaken.

This study replicated the results of Study 1: SA was positively related to relative deprivation, and it was found that people who perceive greater inequality and find a greater disadvantage in the social ladder experience higher SA. These results are congruent with the predictions of Wilkinson and Pickett (2017) on the relationships between economic inequality, socioeconomic status and SA, as well as with the results of other previous studies (Layte \& Whelan, 2014).

\section{Study 3}

In order to provide solid evidence in favour of the relationship between socioeconomic status and SA and further proof of the validity of the Spanish version of the Status Anxiety Scale, a third study was conducted. Another objective of this study was to prove that the Spanish version of the Status Anxiety Scale presented in this article could be used as a dependent variable in studies which seek to analyse the effect of sociostructural factors on SA because it is a measure that is sensitive to these factors (e.g., socioeconomic status and economic inequality). 
In Study 3, which was experimental, we expanded Hypothesis 6 by positing a causal relationship between socioeconomic status and SA. Therefore, we predicted that the people assigned to a low socioeconomic status would show higher SA than those assigned to a high status (Hypothesis 7).

\section{Method}

Participants. A total of 168 Spanish students from the University of Granada participated in this study. It was conducted in university libraries during class time. Twenty-five participants were excluded from the initial sample because they did not complete the task included in the manipulation, along with three participants because they did not meet the age criteria set in the pre-register of the study. The resulting sample was comprised of 140 participants $\left(60 \%\right.$ females; $\left.M_{\text {age }}=22, S D_{\text {age }}=2.79\right)$.

Design. A mixed 2 (Inequality: High vs. Low) x 2 (Family socioeconomic status: High vs. Low) experimental design was used; in the first the variable was manipulated among participants and the second intra-participant (osf.io/ubxet).

Experimental manipulation. Information on two families was presented, one with high and the other with low economic resources. Each participant administered the monthly budget of both families, choosing what amount of money to assign to each of the different spending categories.

Manipulation of socioeconomic status (intra-participant). The only differences between the two families were the names of their members, their total monthly income and their socioeconomic status, as shown in a graphic representation of the income distribution in Spanish society. The family with high resources was situated in the $10^{\text {th }}$ decile while the family with low resources was in the $1^{\text {st }}$ decile. 
Manipulation of perceived inequality (among participants). The participants were randomly assigned to one of two experimental conditions: high economic inequality and low economic inequality. When presenting the position occupied by each family in the income distribution, (false) cut-off points between the income deciles in Spain were presented. Thus, the differences between the experimental high and low inequality conditions lay in the total monthly income available to the two families and in the cut-off points indicated among the deciles. Specifically, both the ratio of the cutoff point of decile 10 and decile 1 and the ratio between the mean income of both families in these population segments were twice the real ratios (5.37 and 12.45, respectively $)^{2}$ in the high inequality condition and half the real ratios in the low inequality condition.

\section{Instruments}

Status anxiety. Each participant filled out two SA measures immediately after they had administered the monthly budget for each of the families. The instructions of the scale were adapted so that the participants answered the items on the scale by imagining how they would feel if they were members of a family with high socioeconomic status $(\alpha=.75)$ or low socioeconomic status $(\alpha=.80$, e.g., "Please think about the life of the García-Pérez family and state to what extent you agree or disagree with the following statements. In other words, how would you answer if you belonged to this family?").

The participants' SSS and OSS were also measured using the same procedure as in Studies 1 and 2. 
Checking the manipulation. To verify the efficacy of the manipulation of perceived inequality, the same items on perceived inequality in Spanish society as in Studies 1 and 2 were included.

Procedure. After reading and accepting the informed consent conditions, the participants filled out the questionnaire individually. As part of the experimental manipulation, after knowing the income and economic status of the two families living in the same city, the participants filled out two tables (e.g., Figure 1), one for each family, choosing the amount of money they felt should be allocated to different categories of monthly expenses while ensuring that the sum of all the amounts allocated to all the expenses did not exceed each family's monthly income. The order in which the task was presented and the SA measure for the two families was counterbalanced.

\section{[FIGURE 1]}

\section{Results}

As predicted in Hypothesis 7, the participants in the low status condition experienced higher $\mathrm{SA}(M=5.12, S D=1.44)$ than those in the high status condition $(M=2.81, S D=$ $\left.1.31 ; F(1,138)=174.77, p<.001, \eta_{\mathrm{p}}^{2}=.56\right) .{ }^{3}$ However, the manipulation of perceived inequality was not effective, given that no significant differences were found among the measures of perceived inequality in the low and high income inequality condition $(F(1$, 138) $\left.=0.58, p=.45, \eta_{p}^{2}=.00\right)$, nor was the interaction between inequality and socioeconomic status significant $\left(F(1,138)=0.55, p=.46, \eta_{\mathrm{p}}^{2}=.00\right)$.

\section{Discussion}

This last study provided experimental evidence of the effect of socioeconomic status on SA. The participants reported higher SA when they experienced a lower socioeconomic 
status. Within a context of increasing inequality as in Spanish society, this result is in line with the predictions of Wilkinson and Pickett (2017) on the increasing differences between the wealthy and poor in unequal societies, as well as with the results of other cross-cultural studies (Layte \& Whelan, 2014). On the other hand, the manipulation of perceived inequality was not effective, so our hypothesis on the predicted effect of perceived inequality on SA was not proven.

\section{General Discussion}

The results of the studies presented show evidence of validity and reliability of the Spanish version of the Status Anxiety Scale. Through two studies and a broad sample of the general population in Spain, the one-factor structure of the scale was confirmed, and evidence in favour of the relationship between SA and theoretically relevant constructs like socioeconomic status, relative deprivation, social comparison and perceived inequality was provided. Furthermore, it was found that SA is not very strongly associated with these variables $(r<.30)$, which reveals the divergent validity of the Spanish version of the Status Anxiety Scale, by measuring individual differences beyond these variables. Therefore, this variable's relevant role in the study of the effects of economic inequality is confirmed, along with scale's capacity to capture individual differences in the way people react to it. The relationships found may indicate that when faced with scenarios of heightened economic inequality, people perceive their environment as more competitive, tend to compare themselves with others and attribute greater importance to economic success, which might lead them to feel a greater concern with their social status in that they feel disadvantaged compared to the rest of society; finally, it may ultimately lead to poorer health (Marmot, 2004b) and wellbeing (Buttrick \& Oishi, 2017). 
The third study also experimentally confirmed that occupying a low socioeconomic status leads people to experience higher SA. This result confirms the findings of previous studies (Layte $\&$ Whelan, 2014). Importantly, these effects remain in place even when controlling for the participants' real socioeconomic status.

On the other hand, these results diverge from those found in other avenues of research, since previous studies seem to indicate that people with medium status (Duguid \& Goncalo, 2015) or high status (Jetten, Mols, Healy, \& Spears, 2017) may suffer the most from SA under certain circumstances. The apparent incongruency in these results may be due to the fact that SA may be moderated by other variables such as perceived stability (Duguid \& Goncalo, 2015; Jetten et al., 2017), meritocratic ideology (García-Sánchez et al., 2018) and perceived social mobility (Schneider, 2012). Future studies can inquire into the role of these variables in the relationship between socioeconomic status, perceived inequality and SA in order to determine under what circumstances people with low status suffer from greater SA in highly unequal societies. Furthermore, replicating the effects of status on SA using validated measures of this construct in cultural contexts different to those in the original studies may increase the ecological validity of these findings, along with the comparability of the effects found. On the other hand, future studies should also test the effects of perceived inequality on SA using experimental paradigms in which economic inequality is manipulated.

On the other hand, we believe that the Status Anxiety Scale, just like other scales that measure anxiety (Endler, Parker, Bagby, \& Cox, 1999), allows this construct to be operationalised through a complex interaction among individual and situational variables. Nonetheless, as shown in this article, the scale can be used to measure status anxiety as a relatively stable individual difference (as in Studies 1 and 2) or as a response to a specific situation (Study 3). 
The validation of the scale in Spain opens new avenues of research for the intercultural study of the predictive variables of SA. Specifically, we can expect that the differences in the attributions of socioeconomic status, meritocratic beliefs and perceived social mobility in different contexts may predict differences in SA beyond the effects of perceived inequality (Bjørnskov, Dreher, Fischer, Schnellenbach, \& Gehring, 2013; Schneider, 2012).

The SA construct may be involved in many of the negative effects traditionally associated with economic inequality (Rodríguez-Bailón, Sánchez-Rodríguez, GarcíaSánchez, Petkanopoulou, \& Willis, 2019). Having a valid, reliable measurement instrument that enables researchers to ascertain the degree to which people are concerned with their social status in society may allow new avenues to research to be pursued which can explain and predict how economic inequality creates dysfunctional societies and affects people's wellbeing, as well as to devise ways in which these processes can be reversed.

\section{Notes}

${ }^{1}$ The MHDI is a standard income indicator which allows for comparisons with other EU countries. It is the outcome of the formula $\mathrm{U}=\mathrm{I} /\left[1+\left(0.5^{*} \mathrm{a}\right)+\left(0.3^{*} \mathrm{~m}\right)\right]$ in which $\mathrm{U}=\mathrm{MHDI}, \mathrm{I}=$ total household income, a $=$ number of adults in the household in addition to the participant, and $\mathrm{m}=$ number of minors under the age of 14 in the household.

\footnotetext{
${ }^{2}$ Mean income per unit of consumption in 2016. Income distribution by deciles. Retrieved from http://ec.europa.eu/eurostat/data/database el 09/04/2017.

${ }^{3}$ These differences remained significant when controlling for the participants' SES and OSS.
} 
Table 1.

Descriptive statistics and correlations among the variables measured in Study 1 and SA

\begin{tabular}{lcccc}
\hline & $M$ & $S D$ & SA & $95 \%$ CI \\
\hline SA & 4.19 & 1.55 & & \\
Relative deprivation & 3.09 & 0.97 & $.27 * *$ & {$[0.15,0.37]$} \\
Social comparison & 2.96 & 0.72 & $.21^{*}$ & {$[0.09,0.32]$} \\
Public self-consciousness & 3.44 & 0.76 & $.23^{* *}$ & {$[0.11,0.34]$} \\
Status-seeking & & & & .09 \\
& 1.65 & 0.74 & & {$[-0.03,0.20]$} \\
\hline Note: $* p<.01 ; * p<.001$ & & & &
\end{tabular}


Table 2.

Study 2. Descriptive statistics and correlations with SA.

\begin{tabular}{lcccc}
\hline & $M$ & $S D$ & SA & $95 \%$ CI \\
\hline SA & 4.24 & 1.59 & & \\
Relative deprivation & 3.12 & 0.98 & $.26^{* *}$ & {$[0.15,0.37]$} \\
Perceived inequality & 5.13 & 1.08 & $.28^{* *}$ & {$[0.16,0.39]$} \\
SES & 4.95 & 3.11 & $-.28^{* * *}$ & {$[-0.41,-0.14]$} \\
OSS & & & & {$[-0.39,-0.16]$} \\
& 5.38 & 1.58 & $-.28^{* *}$ & \\
\hline Note: $* * p<.001$ & & & &
\end{tabular}




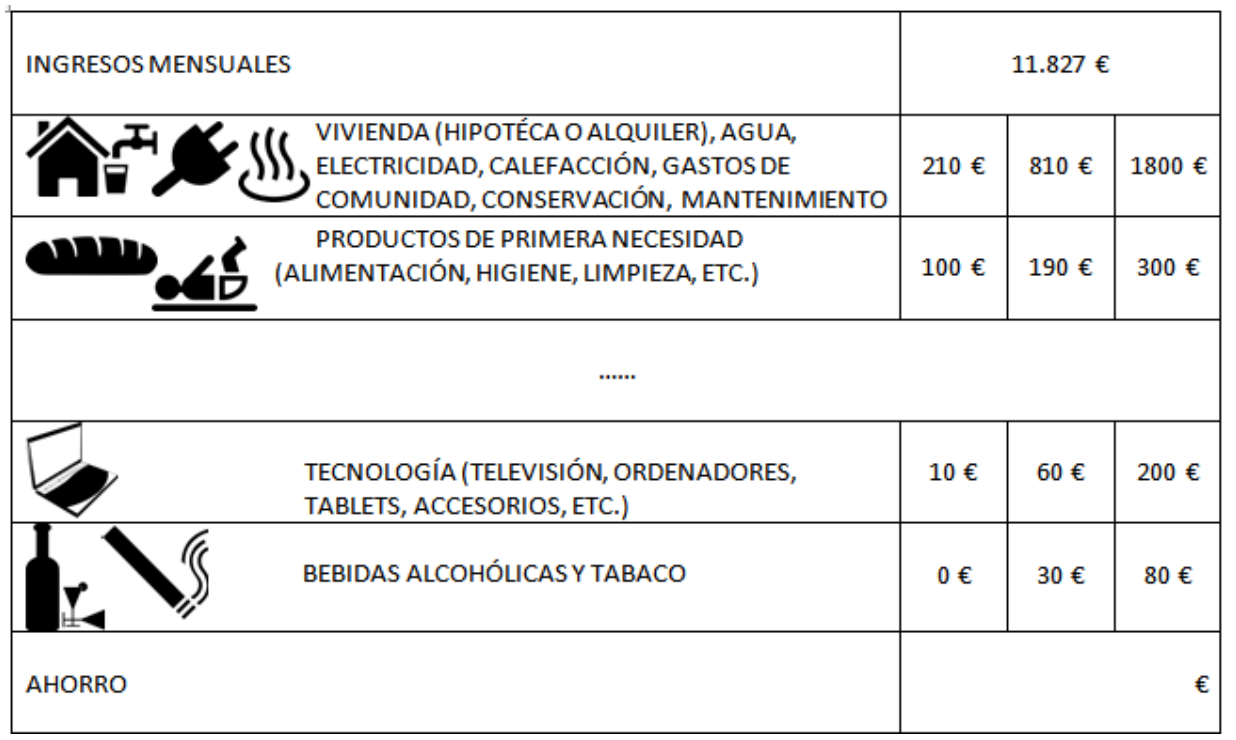

Figure 1. Experimental task used in Study 3.

MONTHLY INCOME

HOUSING (MORTGAGE OR RENT), WATER, ELECTRICITY, HEATING, RESIDENTS' FEES, CONSERVATION, MAINTENANCE

STAPLE PRODUCTS (FOOD, HYGIENE, CLEANING, ETC.)

TECHNOLOGY (TELEVISIONS, COMPUTERS, TABLETS, ACCESSORIES, ETC.)

ALCOHOLIC DRINKS AND TOBACCO

SAVINGS 


\section{Versión española de la Escala de Ansiedad por el Estatus}

Los habitantes de la ciudad española con menor renta per cápita (i.e. Sanlúcar de Barrameda) viven de media 5 años menos que los habitantes de la ciudad con mayor renta per cápita (i.e. Pozuelo de Alarcón; INE, 2019). Esta diferencia no se debe sólo a las condiciones materiales de vida, ya que más allá de sus ingresos, el estatus socioeconómico de una persona determina su salud y esperanza de vida (Marmot, 2004a). Dado que las sociedades actuales son cada vez más desiguales y jeraquizadas (Piketty, 2013), las diferencias socioeconómicas se han vuelto cada vez más importantes (Wilkinson \& Pickett, 2009). En contextos altamente jerarquizados (i.e., en jerarquías de humanos y de primates no humanos), ocupar posiciones de bajo estatus incluso puede inducir cambios metabólicos y del sistema inmunológico que incrementan el riesgo de enfermedades crónicas, como la diabetes y las enfermedades cardiacas (De Vogli, Ferrie, Chandala, Kivimäki \& Marmot, 2006; Marmot, 2004b).

Los seres humanos, al igual que otros mamíferos, atienden a las jerarquías sociales y a la posición de los individuos dentro de ellas. Por ejemplo se ha encontrado que las personas son capaces de identificar rápidamente el estatus socioeconómico de otros desconocidos con muy poca información sobre ellos (Kraus, Park \& Tan, 2017). El deseo de mantener el estatus en una jerarquía o alcanzar un estatus superior es una motivación que puede considerarse parte de nuestra herencia evolutiva (Anderson, Hildreth, \& Howland, 2015). No obstante, en la actualidad las diferencias económicas han convertido el deseo de estatus en una preocupación constante (De Botton, 2004), capaz de causar reacciones de estrés e interferir en la vida de las personas (Gruenewald, Kemeny \& Aziz, 2006).

La experiencia de ansiedad por el estatus (AE) lleva a las personas de cualquier posición social a preocuparse constantemente por no alcanzar los estándares de éxito de 
la sociedad, por quedarse estancadas en su posición social, o por perder su estatus (De Botton, 2004; Paskov, Gërxhani \& van de Werfhorst, 2013). La AE puede provocar conductas más egoístas, menos solidarias (Paskov et al. 2013), y discriminatorias hacia quienes ocupan los últimos peldaños de la escala social (De Botton, 2004; Liu, Soleck, Hopps, Dunston, \& Pickett, 2004). En estudios internacionales con frecuencia se ha utilizado una medida muy general basada en un solo ítem para medir la experiencia de AE (i.e. "Some people look down on me because of my job situation or income"; Delhey \& Dragalov, 2014; Layte \& Whelan, 2014). Sin embargo el uso de un solo ítem para medir constructos psicológicos complejos ha sido criticado por presentar limitaciones en cuanto a la aplicabilidad de los criterios de validez de contenido y las dificultades para demostrar su fiabilidad (Fisher, Matthews \& Gibbons, 2016).

Recientemente, Day y Fiske (2016) desarrollaron en inglés una breve Escala de AE capaz de medir este constructo, de la que obtuvieron buenos indicadores de fiabilidad y validez. En este trabajo presentamos distintas evidencias de validez y fiabilidad de este instrumento en castellano.

\section{Ansiedad por el Estatus}

Las personas experimentan respuestas de estrés ante la posibilidad de perder estatus (Scheepers, Ellemers \& Sintemaartensdijk, 2009) o de no alcanzar los estándares de éxito socioeconómico en su entorno (De Botton, 2004). La preocupación por el propio estatus lleva a las personas a reaccionar negativamente cuando perciben que están siendo evaluadas y que por lo tanto la imagen de sí mismas podría verse amenazada (Gruenewald, Kemeny \& Aziz, 2006). En la práctica clínica, la preocupación por el estatus socioeconómico del que uno/a disfruta ha sido propuesta como origen de algunos trastornos emocionales, bajo rendimiento o fracaso escolar, académico o laboral (Liu, Soleck, Hopps, Dunston \& Pickett, 2004). La relación negativa entre la AE y la 
salud mental pone de manifiesto la importancia de evaluar ésta como potencial factor de riesgo para la salud mental y la necesidad de disponer de instrumentos de medida adecuados para ello (Layte, 2012).

Cuando se analizan los efectos psicosociales de la desigualdad económica, la AE también es un constructo muy utilizado. De hecho, desde varios modelos teóricos se ha planteado que algunas consecuencias negativas de vivir en una sociedad más desigual (e.g. mayor frecuencia de conductas de riesgo, aumento del endeudamiento, aumento de la competitividad y reducción del bienestar subjetivo) se deben, en parte, a la AE generada en estos contextos (Buttrick \& Oishi, 2017; Loughnan et al., 2011; Paskov et al., 2013; Wilkinson \& Pickett, 2009; 2017). En la misma línea, en estudios utilizando encuestas internacionales se ha encontrado que la AE explica la relación negativa entre la desigualdad económica y diversos indicadores de bienestar y de salud (Delhey \& Dragalov, 2013; Layte, 2012).

Asimismo, es importante establecer que la AE es un constructo diferente a otros utilizados en la literatura. Por ejemplo, aunque describe una tendencia de las personas a preocuparse y percibir algunas situaciones como amenazantes, difiere de la ansiedadrasgo (Balsamo et al., 2013), debido a que a diferencia con ésta última, su objeto de preocupación es más específico que el de la ansiedad-rasgo. En el caso de la ansiedad por el estatus la preocupación se centra en el estatus socio-económico, esto es una reacción a la organización social que estructura la sociedad en el que la persona vive (Solak, Jost, Sümer \& Clore, 2012). Difiere además de otros constructos relacionados, como el materialismo (Richins \& Dawson, 1992), la búsqueda de estatus (Paskov et al, 2017) o la preocupación por el estatus (Kaufman, 1957), ya que no hace referencia al sistema de valores de las personas (i.e. en qué medida las personas consideran el éxito 
económico como un valor importante para ellas), sino más bien de la sociedad en general en la que los individuos viven (De Botton, 2004).

Alderson y Katz-Gerro (2016) encontraron que la importancia atribuida por las personas a comparar sus ingresos con los de los demás afecta negativamente a su bienestar subjetivo más allá de sus ingresos. Esta tendencia a la comparación social podría ser mayor entre quienes atribuyen mayor importancia al éxito económico (Kim, Callan, Gheorghiu \& Matthews, 2017), al estatus y a la búsqueda del mismo (Alba, McIlwain, Wheeler \& Jones, 2014). En estudios previos se ha encontrado que la AE lleva a las personas a realizar constantemente comparaciones con quienes disfrutan de un mejor estatus socioeconómico, aumentando así las probabilidades de experimentar privación relativa (Paskov et al., 2013). Además, se ha encontrado que en sociedades desiguales se produce un mayor consumo de bienes con el objeto de señalar estatus, debido a una mayor preocupación de las personas por su propia posición en la jerarquía social (Walasek \& Brown, 2015). En último lugar, las personas con elevados niveles de auto-conciencia pública, es decir preocupadas por la imagen propia ante los demás, se caracterizan por ser altamente vigilantes hacia la valoración de los otros (Scheier \& Carver, 1985). El estatus socioeconómico es un atributo otorgado por los demás (Prinstein, 2017), a menudo asociado con una valoración de la persona (De Botton, 2004; Paskov et al., 2017), por lo que la la auto-conciencia pública y la AE podrían estar relacionadas.

\section{Desarrollo de la versión española de la Escala de Ansiedad por el Estatus}

Con el propósito de disponer de una versión traducida, adaptada y con evidencias de validez de la Escala de Ansiedad por el Estatus en el contexto español, se realizaron dos estudios con muestras independientes. Anteriormente, los ítems en inglés originales de 
la Escala de Ansiedad por el Estatus (Day \& Fiske, 1996) fueron sometidos a un proceso de traducción inversa y a un juicio de expertos en su versión española (Delgado-Rico, Carretero-Dios \& Ruch, 2012; Hambleton, 2005). La escala resultante, compuesta de cinco ítems, fue administrada a una muestra con el fin de explorar sus características psicométricas y su estructura factorial. En el segundo estudio se confirmó su estructura factorial administrando la escala a otra muestra independiente de población general. También se obtuvieron evidencias de fiabilidad y validez de la escala en ambos estudios. Por último, se llevó a cabo un tercer estudio experimental con el fin de aportar evidencias acerca de la relación causal entre el estatus socioeconómico y la AE.

\section{Estudio 1}

Con el fin de analizar las propiedades psicométricas y explorar la estructura factorial de la versión española de la Escala de Ansiedad por el Estatus se realizó un primer estudio, en el que además se obtuvo por primera vez evidencia de la validez convergente de la escala, al analizar su relación esperada con otras medidas. En concreto, se examinó si: los/as participantes que experimentan mayor AE reportan a su vez mayor/es a) privación relativa (Hipótesis 1); b) niveles de búsqueda de estatus (Hipótesis 2); c) tendencia a la comparación (Hipótesis 3) y d) auto-conciencia pública (Hipótesis 4).

Además, por su posible relevancia en relación con el constructo de AE, en el primer estudio se exploraron las relaciones de la AE con la desigualdad económica percibida, tolerancia hacia la desigualdad económica y estatus socioeconómico, así como se incluyeron otras medidas con fines exploratorios. Todas las medidas que se incluyeron en el cuestionario, los análisis y los resultados exploratorios están disponibles en OSF (https://osf.io/7v2wf/). 


\section{Método}

Los ítems de la Escala original de Ansiedad por el Estatus fueron sometidos a traducción inversa y las discrepancias entre las dos versiones en inglés fueron analizadas y resueltas manteniendo el criterio de la máxima fidelidad semántica respecto a la versión original de la escala (Hambleton, 2005). Posteriormente la versión española de los ítems fue sometida a un juicio de expertos (Delgado-Rico, CarreteroDios \& Ruch, 2012). Así, cinco investigadores/as psicólogos/as sociales evaluaron cada ítem de la escala en las dimensiones de representatividad, comprensión, ambigüedad y concisión. Los/as jueces evaluaron todos los ítems en estas dimensiones utilizando una escala Likert de 4 niveles. En el juicio de expertos el orden de los ítems fue aleatorizado y se incluyó un ítem extraído de la versión española de la Escala de Sensación de Poder General (Willis, Carretero-Dios, Rodríguez-Bailón, \& Petkanopoulou, 2016), con el fin de comprobar la validez discriminatoria del juicio de expertos en relación a la dimensión de representatividad del constructo. Este ítem obtuvo un Índice de Validez de Contenido $($ IVC $)=0$ (Índice de acuerdo inter-jueces Kappa $=1)$ indicando que los/as expertos/as discriminaron adecuadamente la representatividad de los ítems. La escala mostró valores de representatividad adecuados (IVC $=.88$ e Índice de acuerdo interjueces Kappa $=.76$ ). Considerando las observaciones de los jueces se aportaron modificaciones mínimas a cuatro de los cinco ítems con el fin de mejorar la comprensión y reducir la ambigüedad de los mismos. En el Apéndice 1 se presenta la versión final de la escala.

Participantes. En el primer estudio participaron 276 personas (55\% mujeres, $34 \%$ hombres, $11 \%$ no indicaron su sexo) de edad comprendida entre los 18 y los 76 años $(M=30.74 D T=14.22)$. Los datos de 6 de estas personas fueron excluidos de los análisis por no ser de nacionalidad española. El 35.8\% de las/os participantes 
pertenecían al primer cuartil en la distribución de Ingresos Medios por Unidad de Consumo en el Hogar (IMUCH) de la población española ${ }^{1}$ (menos de $1.426 €$ al mes en un hogar de 2 adultas/os y un/a menor de 14 años), mientras el 29\% pertenecen al segundo cuartil (entre $1.426 €$ y $2.218 €$ ), el 20.7\% al tercer cuartil (entre $2.218 €$ y $3.248 €$ ) y el $14.5 \%$ al último cuartil (más de $3.248 €$ al mes). El 30.1\% de las/os participantes no indicaron los ingresos percibidos en el hogar.

\section{Instrumentos}

Versión española de la Escala de Ansiedad por el Estatus (Apéndice 1).

Privación Relativa. Se empleó un único ítem ("En los últimos cinco años, ¿cómo dirías que has estado económicamente en comparación a otras personas como tú?"), con escala de respuesta de 5 puntos (1, “mucho mejor”, 5, “mucho peor”). Este ítem mide privación relativa individual (Pettigrew \& Meertens, 1995; Vanneman \& Pettigrew, 1972).

Búsqueda de Estatus. Se utilizó la Escala de Consumo Estatutario (Kilsheimer, 1993). Incluye 5 ítems (e.g. “compraría un producto porque me da estatus”), y utiliza una escala de respuesta tipo Likert del 1 (totalmente en desacuerdo) a 5 (totalmente de acuerdo). La fiabilidad de la escala fue adecuada $(\alpha=.75)$, no obstante, las respuestas de los participantes se agruparon en el extremo inferior de la escala $(M=1.64 D T=$ $0.74)$.

Comparación Social. Se utilizó la INCOM-E (Buunk, Belmont, Peiró, Zurriaga \& Gibbons, 2005). Una escala compuesta por 11 ítems que miden la tendencia de las personas a compararse con los demás (e.g. "A menudo, me comparo con otros respecto a lo que he conseguido en la vida"), con formato de respuesta tipo Likert del 1 
("totalmente en desacuerdo") a 5 ("totalmente de acuerdo"). La fiabilidad de la escala fue adecuada $(\alpha=.82 ; M=2.96 D T=0.72)$.

Auto-conciencia Pública. Se utilizó la sub-escala de auto-conciencia pública de la Escala de Auto-conciencia, adaptada y validada en población española (LópezBonilla \& López-Bonilla, 2010; Scheier \& Carver, 1985). Dicha sub-escala se compone de 7 ítems (e.g. "Me intereso por lo que los demás piensen de mí”). Utiliza una escala de respuesta tipo Likert del 1 ("totalmente en desacuerdo") a 5 ("totalmente de acuerdo"). La fiabilidad de la escala fue adecuada $(\alpha=.78 ; M=3.44 D T=0.76)$.

Estatus Socioeconómico Subjetivo (SSS por sus siglas en inglés). Se utilizó la Escala de MacArthur (Adler, 2001). Los participantes indicaron en una escala entre el 1 y el 10 dónde se situaban en comparación con el resto de la sociedad española en el momento presente, teniendo en cuenta sus recursos, dinero, educación y trabajo.

Estatus Socioeconómico Objetivo (SES por sus siglas en inglés). Se calculó para cada participante el decil de ingresos correspondiente en función del IMUCH según datos de Eurostat (http://ec.europa.eu/eurostat/data/database).

Desigualdad percibida. Se utilizaron dos ítems para preguntar a los/las participantes por la percepción general de desigualdad económica: “¿En qué medida piensas que respecto a la distribución de recursos económicos la sociedad española en la actualidad es desigual (igualitaria)?". La media de ambos fue utilizada como indicador de desigualdad económica percibida $(r=.45, p<.001)$.

Tolerancia hacia la desigualdad. Se empleó un ítem, tradicionalmente utilizado en estudios previos (García-Sánchez, Van der Toorn, Rodríguez-Bailón, \& Willis, 2018) e incluido en la International Social Survey ("Las diferencias de ingresos en España son demasiado grandes"). 


\section{Procedimiento}

Se realizó una encuesta por muestreo incidental en la estación de autobuses de una capital de una provincia andaluza (España). Cada participante, tras leer y aceptar un documento de consentimiento informado, contestó individualmente, de forma anónima y confidencial a los ítems del cuestionario empleando aproximadamente 15 minutos. Además de las medidas descritas, el cuestionario contenía algunas escalas no relacionadas con este estudio (disponibles en https://osf.io/7v2wf/). Todos los estudios incluidos en este artículo fueron aprobados por el comité de ética de la universidad de filiación de las/os autoras/es principales.

\section{Resultados}

Los ítems mostraron índices de discriminación (indicados por la correlación del ítem con el total corregido) comprendidos entre .60 y .81, y buena capacidad para recoger las variaciones de los participantes en el constructo medido $\left(D T_{\text {todos los ítems }}>1\right)$. La media de la escala fue cercana al punto medio $(M=4.19 ; D T=1.55)$.

El resultado de la prueba de esfericidad de Bartlett $\left(\chi^{2}=599.18 ; p<.001\right)$ y el índice KMO (.84) indicaron la idoneidad de la matriz de correlaciones para el análisis factorial exploratorio de la escala mediante extracción de componentes principales.

El análisis factorial exploratorio arrojó un único factor con autovalor superior a 1, que explica el $65 \%$ de la varianza. Las saturaciones de los ítems en este factor oscilaron entre .74 y .89 .

La escala mostró una buena consistencia interna $(\alpha=.86)$, y como se puede observar en la Tabla 1, mostró evidencias de validez convergente al relacionarse con todas las variables hipotetizadas. Solamente no se relacionó con la búsqueda de estatus 
medida a través del consumo estatutario. Esto pudo deberse a que las puntuaciones en esta escala fueron extremadamente bajas $(M=1.65 ; D T=0.74)$, posiblemente debido a la deseabilidad social, y por tanto se pudo producir un efecto "suelo" en sus puntuaciones.

[TABLA 1]

\section{Análisis exploratorios}

La AE resultó positivamente relacionada con la percepción de desigualdad ( $r=$ $.32 ; p<.001,95 \%$ CI $[0.21,0.42])$ y con intolerancia hacia la misma ("las diferencias de ingresos en España son demasiado grandes"; $r=.22 ; p<.001,95 \%$ CI $[0.11,0.33])$, y negativamente con el SSS $(r=-.38 ; p<.001,95 \%$ CI $[-0.49,-0.28])$ y el SES $(r=-$ $.27 ; p<.001,95 \%$ CI $[-0.39,-0.13])$, siendo las personas de bajo estatus quienes experimentan mayor AE.

\section{Discusión}

En el presente estudio se obtuvo evidencia de la estructura unifactorial de la escala. Así mismo se encontró que la escala presenta una fiabilidad adecuada. Se obtuvo además evidencia de validez convergente de la escala al relacionarse positivamente esta última con los constructos de privación relativa, comparación social y auto-conciencia pública. También se encontró, en distintos análisis exploratorios, que se relacionó de forma negativa con el estatus socioeconómico y de forma positiva con la percepción y la (in)tolerancia hacia la desigualdad. La Versión Española de la Escala de Ansiedad por el Estatus aporta por tanto un instrumento con buenos índices de fiabilidad. Además muestra relaciones con constructos relevantes para el estudio de las causas y consecuencias de la AE. 


\section{Estudio 2}

Siguiendo el mismo procedimiento que en el Estudio 1, se llevó a cabo un segundo estudio con el objetivo de confirmar la estructura unifactorial de la Escala de Ansiedad por el Estatus y aportar más evidencias de su validez. En el Estudio 1, de forma exploratoria, se encontró que la AE se relacionó positivamente con la desigualdad percibida y negativamente con el estatus socioeconómico. Este resultado puede deberse a que la desigualdad económica aumenta la distancia social entre quienes ocupan distintas posiciones en la jerarquía social (Wilkinson \& Pickett, 2009), lo que lleva a los individuos a preocuparse por la posición social que ocupan y la que desean alcanzar. La AE podría explicar en parte algunos de los efectos psicosociales de la desigualdad económica (Paskov et al., 2013), por lo que nos propusimos replicar estos resultados en el Estudio 2. Predecimos por lo tanto que: a) La AE se relacionaría positivamente con la desigualdad percibida (Hipótesis 5),y b) negativamente con el estatus social subjetivo (SSS) y el estatus socioeconómico objetivo, indicado por el decil de ingresos (SES) (Hipótesis 6a y 6b).

En el segundo estudio además, nos propusimos replicar el resultado obtenido en el Estudio 1 en relación a la Hipótesis 1, esto es, que la AE se asocia positivamente a la privación relativa.

En este segundo estudio se incluyeron medidas de otros constructos teóricamente relacionados con la $\mathrm{AE}$ con fines exploratorios así como otras medidas no incluidas en este estudio. Estas medidas, los análisis y los resultados exploratorios están disponibles en OSF (https://osf.io/jbdhq/).

\section{Método}


Participantes. Participaron 269 personas (53\% mujeres, 33\% hombres, 14\% no indicaron el sexo) de edad comprendida entre 18 y 73 años $(M=30.88, D T=13.93)$. El $38.5 \%$ pertenecen al primer cuartil de ingresos, el $25.1 \%$ al segundo cuartil, el $17.6 \%$ al tercer cuartil y el $18.7 \%$ al último cuartil. El $30.5 \%$ de las/os participantes no indicaron los ingresos percibidos en el hogar.

Los datos de 11 de estas personas fueron excluidos de los análisis al no ser de nacionalidad española.

Instrumentos. Al igual que en el Estudio 1, en este segundo estudio se incluyó la Versión española de la Escala de Ansiedad por el Estatus y las mismas medidas de privación relativa, de desigualdad percibida, de SSS, y SES previamente utilizadas.

\section{Resultados}

Puesto que la definición teórica del constructo implica una estructura unidimensional de la escala y que el análisis factorial exploratorio en el Estudio 1 arrojó un único factor, se llevó a cabo un análisis factorial confirmatorio por medio del estimador robusto de máxima verosimilitud y se determinó el ajuste del modelo a través de la valoración conjunta de los índices Root Mean Square Error of Approximation (RMSEA), Standarized Root Mean Square Residual (SRMR) y Comparative Fit Index (CFI) (Kaplan, 2000). Estas medidas de ajuste indicaron un modelo unidimensional aceptable $(R M S E A=.00, S R M R=.01, C F I=1)$. El único factor de la escala también mostró una buena fiabilidad $(\alpha=.87)$.

En la Tabla 2 se muestran las correlaciones de la versión española de la Escala de Ansiedad por el Estatus con la medida de privación relativa, desigualdad percibida, SSS y SES. Se replicaron los resultados del Estudio 1 en relación a la Hipótesis 1 al encontrarse una relación positiva entre la AE y privación relativa. 
Nuevamente se encontró evidencia de validez, aportada por la correlación positiva entre la AE y la desigualdad percibida, predicha en la Hipótesis 5 y por la correlación negativa entre la AE y el SSS y el SES, predicha en la Hipótesis 6.

[TABLA 2]

\section{Discusión}

En el Estudio 1 encontramos evidencia de fiabilidad de la versión española de la Escala de Ansiedad por el Estatus, así como de su estructura unifactorial. En este segundo estudio se confirmó esta estructura unifactorial de la escala, al mostrar el modelo de un solo factor un ajuste adecuado en el Análisis Factorial Confirmatorio llevado a cabo.

En el presente estudio se replicaron los resultados del Estudio 1: la AE resultó positivamente relacionada con la privación relativa y se encontró que las personas que perciben mayor desigualdad y las que se encuentran en mayor desventaja en la escala social experimentan mayor AE. Estos resultados son congruentes con las predicciones de Wilkinson y Pickett (2017) acerca de las relaciones entre desigualdad económica, estatus socioeconómico y AE, así como con los resultados de otros estudios anteriores (Layte \& Whelan, 2014).

\section{Estudio 3}

Con el fin de proporcionar evidencias sólidas en favor de la relación entre estatus socioeconómico y AE y de aportar mayor prueba de validez de la versión española de la Escala de Ansiedad por el Estatus se llevó a cabo un tercer estudio. Este estudio tuvo además como objetivo mostrar que la versión española de la Escala de Ansiedad por el Estatus presentada en este artículo puede utilizarse como variable dependiente en los estudios que tengan como objetivo analizar los efectos de factores socio-estructurales 
sobre la AE, al ser una medida sensible a estos factores (e.g., estatus socioeconómico y desigualdad económica).

En este tercer estudio, de corte experimental, ampliamos nuestra Hipótesis 6, al postular una relación de causalidad del estatus socioeconómico sobre la AE. Por lo tanto, predecimos que las personas asignadas a un estatus socioeconómico bajo, mostrarían una mayor AE que las asignadas a un estatus alto (Hipótesis 7).

\section{Método}

Participantes. Participaron en este estudio 168 estudiantes de la Universidad de Granada de nacionalidad española. El estudio se llevó a cabo en bibliotecas universitarias en horario lectivo. De la muestra inicial se excluyeron 25 participantes por no haber completado la tarea incluida en la manipulación y 3 participantes por no cumplir los criterios de edad fijados en el pre registro del estudio. La muestra resultante estuvo compuesta por 140 participantes $\left(60 \%\right.$ mujeres; $\left.M_{\text {edad }}=22, D T_{\text {edad }}=2.79\right)$.

Diseño. Se utilizó un diseño experimental mixto 2 (Desigualdad: Alta vs. Baja) x 2 (Estatus socioeconómico de la familia: Alto vs. Bajo), siendo la primera una variable manipulada entre participantes y la segunda intra participantes (osf.io/ubxet).

Manipulación experimental. Se presentó información sobre dos familias, una de altos y otra de bajos recursos económicos. Cada participante administró el presupuesto mensual de ambas familias, eligiendo qué cantidad de dinero asignaría cada una de ellas a diversas categorías de gasto.

Manipulación del estatus socioeconómico (intra participantes). Las únicas diferencias entre las dos familias fueron los nombres de sus miembros, los ingresos mensuales totales y su estatus socieconómico, mostrado en una representación gráfica 
de la distribución de ingresos de la sociedad española. La familia de altos recursos se situó en el decil 10, mientras la familia de bajos recursos se situó en el decil 1.

Manipulación de la desigualdad percibida (entre participantes). Los participantes fueron asignados aleatoriamente a una de dos condiciones experimentales: alta desigualdad y baja desigualdad económica. Al presentar la posición ocupada por cada familia en la distribución de ingresos, se indicaron puntos de corte (falsos) entre los deciles de ingresos en España. Así las diferencias entre las condiciones experimentales de alta y baja desigualdad residían en los ingresos mensuales totales disponibles para las dos familias y en los puntos de corte indicados entre los deciles. Concretamente, tanto la ratio del punto de corte del decil 10 y el decil 1, como la ratio entre los ingresos medios de dos familias de estos segmentos de población fueron el doble de las ratios reales (éstas son 5.37 y 12.45 respectivamente) ${ }^{2}$ en la condición de alta desigualdad, mientras fueron la mitad de las ratios reales en la condición de baja desigualdad.

\section{Instrumentos}

Ansiedad por el estatus. Cada participante completó dos medidas de AE inmediatamente después de administrar el presupuesto mensual para cada una de las dos familias. Se adaptaron las instrucciones de la escala, de manera que los participantes contestaran a los ítems de la escala imaginando cómo se sentirían si fueran miembros de una familia de alto estatus socioeconómico $(\alpha=.75)$ o de bajo estatus socioeconómico $(\alpha=.80$, e. g. "Te pedimos que pienses en la vida de los García-Pérez y expreses tu grado de acuerdo o desacuerdo con estas afirmaciones. ¿Cómo contestarías si pertenecieras a esta familia?"). 
Se midieron además el SSS y el SES de los participantes por el mismo procedimiento empleado en los estudios 1 y 2.

Comprobación de la Manipulación. Para verificar la eficacia de la manipulación de la desigualdad percibida se incluyeron los mismos items sobre la desigualdad percibida en la sociedad española incluidos en los estudios 1 y 2.

Procedimiento. Las/os participantes, tras leer y aceptar las condiciones del consentimiento informado, rellenaron el cuestionario individualmente. Como parte de la manipulación experimental, tras conocer los ingresos y la posición económica de dos familias residentes en la misma ciudad, las/os participantes completaron dos tablas (e.g., Figura 1), una para cada familia, seleccionando la cantidad de dinero que considerarían oportuno destinar a diversas categorías de gastos mensuales, asegurándose de que la suma de las cantidades asignadas a todos los gastos en su conjunto no superara los ingresos mensuales de cada familia. El orden de presentación de la tarea y de la medida de AE para las dos familias fue contrabalanceado.

\section{[FIGURA 1]}

\section{Resultados}

Tal y cómo se predijo en la Hipótesis 8 , los participantes experimentaron mayor AE en la condición de bajo estatus $(M=5.12, D T=1.44)$ que en la condición de alto estatus $\left(M=2.81, D T=1.31 ; F(1,138)=174.77, p<.001, \eta_{p}^{2}=.56\right)^{3}$. Sin embargo, la manipulación de la desigualdad percibida no fue efectiva, puesto que no se encontraron diferencias significativas entre las medidas de desigualdad percibida en la condición de baja y alta desigualdad $\left(F(1,138)=0.58, p=.45, \eta_{\mathrm{p}}^{2}=.00\right)$. Tampoco fue significativa la interacción entre la desigualdad y el estatus socioeconómico $(F(1,138)=0.55, p=$ $\left..46, \eta_{p}^{2}=.00\right)$. 


\section{Discusión}

En este último estudio se obtuvo evidencia experimental del efecto producido por el estatus socioeconómico sobre la AE. Los/as participantes reportaron mayor AE cuando experimentaron un estatus socioeconómico más bajo. Este resultado, en un contexto de creciente desigualdad como el de la sociedad española, se encuentra en línea con las predicciones de Wilkinson y Pickett (2017) sobre el aumento de las diferencias entre ricos y pobres en sociedades desiguales, así como con los resultados de otros estudios transculturales (Layte \& Whelan, 2014). Por otro lado, la manipulación de la desigualdad percibida no fue efectiva, por lo que no se pudo contrastar nuestra hipótesis del efecto predicho de la desigualdad percibida sobre la AE.

\section{Discusión General}

Los resultados de los estudios presentados muestran evidencia de validez y fiabilidad de la versión española de la Escala de Ansiedad por el Estatus. A través de dos estudios, y con la participación de una amplia muestra de población general española, se confirmó la estructura unifactorial de la escala, se han aportado evidencias a favor de la relación entre la $\mathrm{AE}$ y constructos teóricamente relevantes, como el estatus socioeconómico, la privación relativa, y la comparación social o la desigualdad percibida. Además, la AE se relaciona de forma no muy alta con estas variables con la AE $(r<.30)$, lo cual pone de manifiesto la validez divergente de la Versión Española de Ansiedad por el Estatus, al medir diferencias individuales más allá de dichas variables. Por lo tanto se confirma el rol de esta variable como relevante en el estudio de los efectos de la desigualdad económica y la capacidad de la escala para captar diferencias individuales en la forma en que las personas reaccionan ante ella. La relaciones encontradas, por ejemplo, podrían estar indicando que ante escenarios de elevada 
desigualdad económica las personas perciben su entorno como más competitivo, tienden a compararse con las demás personas y atribuyen mayor importancia al éxito económico, lo que las llevaría a sentir mayor preocupación por su posición social, a sentirse en desventaja respecto al resto de la sociedad, y en último término a tener menores niveles de salud (Marmot, 2004b) y bienestar (Buttrick \& Oishi, 2017).

En un tercer estudio además, se confirmó experimentalmente que ocupar una posición de bajo estatus socioeconómico lleva a las personas a experimentar mayor AE. Este resultado confirma los hallazgos de anteriores estudios (Layte \&Whelan, 2014). De forma importante, estos efectos se mantienen incluso al controlar el estatus socioeconómico real de los/las participantes.

Por otro lado, estos resultados divergen de los obtenidos en otras líneas de investigación, ya que estudios anteriores parecen indicar que las personas de estatus medio (Duguid \& Goncalo, 2015) o de estatus alto (Jetten, Mols, Healy \& Spears, 2017) podrían ser las que más sufren AE en determinadas circunstancias. La aparente incongruencia entre estos resultados podría deberse a que ésta puede ser moderada por otras variables como la estabilidad percibida (Duguid \& Goncalo, 2015; Jetten et al., 2017), la ideología meritocrática (García-Sánchez et al., 2018), o la movilidad social percibida (Schneider, 2012). Futuras investigaciones podrían indagar sobre el papel de estas variables en la relación entre estatus socioeconómico, desigualdad percibida y AE con el fin de establecer bajo qué circunstancias las personas de bajo estatus sufren mayor AE en sociedades altamente desiguales. Además, replicar los efectos del estatus sobre la AE utilizando medidas validadas de este constructo y en contextos culturales diferentes al de los estudios originales podría aumentar la validez ecológica de estos hallazgos y la comparabilidad de los efectos encontrados. Por otro lado, futuros estudios 
deberían de poner a prueba los efectos de la desigualdad percibida sobre la AE a través de paradigmas experimentales en los que se manipule la desigualdad económica.

Por otro lado, creemos que la Escala de Ansiedad por el Estatus, al igual que sucede con otras escalas que miden la ansiedad (Endler, Parker, Bagby \& Cox, 1999), permite operacionalizar este constructo como el resultado de una interacción compleja entre variables individuales y situacionales. A pesar de esto, y como se ha mostrado en este artículo, la escala puede ser utilizada para medir la ansiedad por el estatus como una diferencia individual relativamente estable (como sucede en los Estudios 1 y 2) o como una respuesta ante una situación concreta (Estudio 3).

La validación de la escala en España permite abrir nuevas líneas de investigación para el estudio transcultural de las variables predictoras de la AE. En concreto, cabría esperar que las diferencias en relación a las atribuciones sobre el estatus socioeconómico, las creencias meritocráticas y la movilidad social percibida entre diferentes contextos puedan predecir diferencias en la AE más allá de los efectos de la desigualdad percibida (Bjørnskov, Dreher, Fischer, Schnellenbach \& Gehring, 2013; Schneider, 2012).

El constructo de AE podría estar involucrado en muchos de los efectos negativos tradicionalmente asociados con la desigualdad económica (Rodríguez-Bailón, SánchezRodríguez, García-Sánchez, Petkanopoulou, \& Willis, 2019). Contar con un instrumento de medida válido y fiable que permita conocer el grado en que las personas se preocupan por la propia posición en la sociedad podría permitir desarrollar nuevas líneas de investigación que permitan explicar y predecir cómo la desigualdad económica crea sociedades disfuncionales y repercute en el bienestar de las personas, así como idear formas en las que se pueden revertir estos procesos. 


\section{Notas}

${ }^{1}$ El IMUCH es un indicador estándar de ingresos que permite comparaciones con otros países de la UE. Es resultante de la fórmula $\mathrm{U}=\mathrm{I} /[1+(0,5 * \mathrm{a})+(0,3 * \mathrm{~m})]$. Donde $\mathrm{U}=\mathrm{IMUCH}, \mathrm{I}=$ ingresos totales del hogar, $\mathrm{a}=$ número de adultos adicionales además del participante en el hogar, y $\mathrm{m}=$ número de menores de 14 años en el hogar.

${ }^{2}$ Ingresos medios por unidad de consumo en 2016. Distribución de ingresos por deciles. Consultado en http://ec.europa.eu/eurostat/data/database el 09/04/2017.

${ }^{3}$ Estas diferencias continuaron siendo significativas al controlar por SES y SSS de las/os participantes. 
Tabla 1.

Descriptivos y correlaciones entre las variables medidas en el Estudio 1 y la AE

\begin{tabular}{|c|c|c|c|c|}
\hline & $M$ & $D T$ & $\mathrm{AE}$ & $95 \% \mathrm{CI}$ \\
\hline $\mathrm{AE}$ & 4.19 & 1.55 & & \\
\hline Privación relativa & 3.09 & 0.97 & $.27 * *$ & {$[0.15,0.37]$} \\
\hline Comparación social & 2.96 & 0.72 & $.21 *$ & {$[0.09,0.32]$} \\
\hline Auto-conciencia pública & 3.44 & 0.76 & $.23 * *$ & {$[0.11,0.34]$} \\
\hline Búsqueda de estatus & 1.65 & 0.74 & .09 & {$[-0.03,0.20]$} \\
\hline
\end{tabular}


Tabla 2.

Estudio 2. Descriptivos y correlaciones con AE.

\begin{tabular}{lcccc}
\hline & $M$ & $D T$ & AE & $95 \%$ CI \\
\hline AE & 4.24 & 1.59 & & \\
Privación relativa & 3.12 & 0.98 & $.26^{* *}$ & {$[0.15,0.37]$} \\
Desigualdad percibida & 5.13 & 1.08 & $.28^{* *}$ & {$[0.16,0.39]$} \\
SES & 4.95 & 3.11 & $-.28^{* *}$ & {$[-0.41,-0.14]$} \\
SSS & & & & {$[-0.39,-0.16]$} \\
& 5.38 & 1.58 & $-.28 * *$ & \\
\hline Nota: $* * p<.001$ & & & &
\end{tabular}




\begin{tabular}{|c|c|c|c|c|}
\hline INGRESOS MENSUALES & \multicolumn{3}{|c|}{$11.827 €$} \\
\hline $\begin{array}{c}\text { PRODUCTOS DE PRIMERA NECESIDAD } \\
\text { (ALIMENTACIÓN, HIGIENE, LIMPIEZA, ETC.) }\end{array}$ & $100 €$ & $190 €$ & $300 €$ \\
\hline TECNOLOGÍA (TELEVISIÓN, ORDENADORES, \\
TABLETS, ACCESORIOS, ETC.)
\end{tabular}

Figura 1. Tarea experimental empleada en el Estudio 3. 


\section{Acknowledgements / Agradecimientos}

This study was conducted as part of the R\&D excellence project "Society of wealthy and poor: Psychosocial consequences of economic inequality" (ref. PSI2016-78839-P), financed by the State Research Agency of the government of Spain and by the European Social Fund as part of the 2017 call for applications for assistance for predoctoral contracts to train $\mathrm{PhDs}$ (ref. BES-2017-082707). El presente trabajo se ha realizado dentro del proyecto de excelencia $I+D$ "Sociedad de ricos y pobres: Consecuencias psicosociales de la desigualdad económica." (ref. PSI2016-78839-P), financiado por la Agencia Estatal de Investigación del Gobierno de España y el Fondo Social Europeo, en el marco de la convocatoria correspondiente al año 2017 de ayudas para contratos predoctorales para la formación de doctores (ref. BES-2017-082707).

\section{References / Referencias}

Adler, N. E. (2001). A consideration of multiple pathways from socioeconomic status to health. In J. A. Auerbach \& B. K. Krimgold (Eds.), Income, Socioeconomic Status, and Health: Exploring the Relationships. Washington, D. C.: National Policy Association.

Alba, B., McIlwain, D., Wheeler, L., \& Jones, M. P. (2014). Status consciousness. A preliminary construction of a scale measuring individual differences in statusrelevant attitudes, beliefs, and desires. Journal of Individual Differences, 35, 166-176. doi:10.1027/1614-0001/a000143

Alderson, A. S., \& Katz-Gerro, T. (2016). Compared to whom? Inequality, social comparison, and happiness in the United States. Social Forces, 95, 25-54. doi: $10.1093 /$ sf/sow042

Anderson, C., Hildreth, J. A., \& Howland, L. (2015). Is the desire for status a fundamental human motive? A review of the empirical literature. Psychological Bulletin. doi: $\underline{10.1037 / \mathrm{a} 0038781}$ 
Balsamo, M., Romanelli, R., Innamorati, M., Ciccarese, G., Carlucci, L., \& Saggino, A. (2013). The state-trait anxiety inventory: Shadows and lights on its construct validity. Journal of Psychopathology and Behavioral Assessment, 35, 475-486. doi: $\underline{10.1007 / \mathrm{s} 10862-013-9354-5}$

Bjørnskov, C., Dreher, A., Fischer, J. A., Schnellenbach, J., \& Gehring, K. (2013). Inequality and happiness: When perceived social mobility and economic reality do not match. Journal of Economic Behavior \& Organization, 91, 75-92. doi: $10.1016 /$ j.jebo.2013.03.017

Buunk, A. P., Belmont, J., Peiró, J. M., Zurriaga, R., \& Gibbons, F. X. (2005). Diferencias individuales en la comparación social: Propiedades de la Escala Española de Orientación Hacia la Comparación Social. Revista Latinoamericana de Psicología, 37, 561-579.

Buttrick, N. R., \& Oishi, S. (2017). The psychological consequences of income inequality. Social and Personality Psychology Compass, 11, 1-12. doi: $\underline{10.1111 / \mathrm{spc} 3.12304}$

Day, M.V., \& Fiske, S. T. (July, 2016). What is status anxiety? Exploring a mechanism of the consequences of income inequality. Presentation at the International Society for Justice Research (ISJR), 16th Biennual Conference, Canterbury, U.K.

De Botton, A. (2004) Status Anxiety. London: Penguin.

Delgado-Rico, E., Carretero-Dios, H., \& Ruch, W. (2012). Content validity evidences in test development: An applied perspective. International Journal of Clinical and Health Psychology, 12. doi:10.5167/uzh-64551 
Delhey, J., \& Dragolov, G. (2014). why inequality makes europeans less happy: The role of distrust, status anxiety, and perceived conflict. European Sociological Review, 30, 151-165. doi:10.1093/esr/jct033

De Vogli, R., Ferrie, J. E., Chandola, T., Kivimäki, M., \& Marmot, M. G. (2007). Unfairness and health: evidence from the Whitehall II Study. Journal of Epidemiology \& Community Health, 61, 513-518. doi:10.1136/jech.2006.052563

Duguid, M. M., \& Goncalo, J. A. (2015). Squeezed in the middle: The middle status trade creativity for focus. Journal of Personality and Social Psychology, 109, 589-603. doi: $\underline{10.1037 / a 0039569}$

Endler, N. S., Parker, J. D., Bagby, R. M., \& Cox, B. J. (1991). Multidimensionality of state and trait anxiety: Factor structure of the Endler Multidimensional Anxiety Scales. Journal of Personality and Social Psychology, 60, 919-926. doi:10.1037//0022-3514.60.6.919

Fisher, G. G., Matthews, R. A., \& Gibbons, A. M. (2016). Developing and investigating the use of single-item measures in organizational research. Journal of Occupational Health Psychology, 21, 3-23. doi: $\underline{10.1037 / a 0039139}$

García-Sánchez, E., Van der Toorn, J., Rodríguez-Bailón, R., \& Willis, G. B. (2018). The vicious cycle of economic inequality: The role of ideology in shaping the relationship between "what is" and "what ought to be" in 41 countries. Social Psychological and Personality Science. doi:10.1177/1948550618811500

Gruenewald, T. L., Kemeny, M. E., \& Aziz, N. (2006). Subjective social status moderates cortisol responses to social threat. Brain, Behavior, and Immunity, 20, 410-419. doi:10.1016/j.bbi.2005.11.005 
Hambleton, R. K. (2005). Issues, designs and technical guidelines for adapting tests into multiple languages and cultures. In R. K., Hambleton, P. F., Merenda \& S.D. Spielberger (Eds.), Adapting Educational and Psychological Tests for CrossCultural Assessment (pp. 3-38). Mahwah, NJ: Lawrence Erlbaum Associates.

INE (29 de Mayo, 2019) Indicadores urbanos [tablas dinámicas]. Retrieved from https://www.ine.es/jaxiT3/Tabla.htm?t $=30140$

Jetten, J., Mols, F., Healy, N., \& Spears, R. (2017), “Fear of falling”: Economic instability enhances collective angst among societies' wealthy class. Journal of Social Issues, 73, 61-79. doi:10.1111/josi.12204

Kaplan, D. (2000). Structural equation modeling: Foundations and extensions. Thousand Oakes, CA: SAGE.

Kaufman, W. C. (1957). Status, authoritarianism, and anti-semitism. American Journal of Sociology, 62(4), 379-382. doi: $10.1086 / 222034$

Kilsheimer, J. C. (1993). Status consumption: The development and implications of a scale measuring the motivation to consume for status (Doctoral Dissertation). The Florida State University.

Kim, H., Callan, M. J., Gheorghiu, A. I., \& Matthews, W. J. (2017). Social comparison, personal relative deprivation, and materialism. British Journal of Social Psychology, 56, 373-392. doi:10.1111/bjso.12176

Kraus, M. W., Park, J. W., \& Tan, J. J. (2017). Signs of social class: The experience of economic inequality in everyday life. Perspectives on Psychological Science, 12, 422-435. doi: $\underline{10.1177 / 1745691616673192}$ 
Layte, R. (2012). The association between income inequality and mental health: Testing Status anxiety, social capital, and neo-materialist explanations. European Sociological Review, 28, 498-511. doi:10.1093/esr/jcr012

Layte, R., \& Whelan, C. T. (2014). Who feels inferior? A test of the status anxiety hypothesis of social inequalities in health. European Sociological Review, 30, 525-535. doi:10.1093/esr/jcu057

Liu, W. M., Soleck, G., Hopps, J., Dunston, K., \& Pickett Jr, T. (2004). A new framework to understand social class in counseling: The social class worldview model and modern classism theory. Journal of Multicultural Counseling and Development, 32, 95-122. doi:10.1002/j.2161-1912.2004.tb00364.x

López-Bonilla, J. M., \& López-Bonilla, L. M. (2010). Autoconciencia en el ámbito del consumidor: Revisión teórica y operatividad del constructo. Revista electrónica de motivación y emoción, 13, 62-76.

Loughnan, S., Kuppens, P., Allik, J., Balazs, K., De Lemus, S., Dumont, K., ... \& Park, J. (2011). Economic inequality is linked to biased self-perception. Psychological Science, 22, 1254-1258. doi:10.1177/0956797611417003

Marmot, M. (2004a). Status syndrome. London: Bloomsbury Publishing.

Marmot, M. (2004b). Status syndrome. Significance, 1, 150-154. doi:10.1111/j.17409713.2004.00058.x

Paskov, M., Gërxhani, K., \& van de Werfhorst, H. G. (2013). Income inequality and status anxiety. Growing Inequality Impacts, 90, 1-46.

Pettigrew, T. F., \& Meertens, R. W. (1995), Subtle and blatant prejudice in Western Europe. Eur. J. Soc. Psychol., 25, 57-75. doi:10.1002/ejsp.2420250106 
Piketty, T. (2013). Le Capital au XXIe siècle. Paris: Seuil.

Prinstein (2017). Popular: The power of likability in a status-obsessed world. New York, NY: Viking.

Richins, M. L., \& Dawson, S. (1992). A consumer values orientation for materialism and its measurement: Scale development and validation. Journal of Consumer Research, 19, 303-316. doi:10.1086/209304

Rodríguez-Bailón, R., Sánchez-Rodríguez, Á., García-Sánchez, E., Petkanopoulou, K., \& Willis, G. B. (2019). Inequality is in the air: Contextual psychosocial effects of power and social class. Current Opinion in Psychology, 33, 120-125. doi: $10.1016 /$ j.copsyc.2019.07.004

Scheepers, D., Ellemers, N., \& Sintemaartensdijk, N. (2009). Suffering from the possibility of status loss: Physiological responses to social identity threat in high status groups. European Journal of Social Psychology, 39, 1075-1092. doi:10.1002/ejsp.609

Scheier, M. F. \& Carver, C. S. (1985), The Self-Consciousness Scale: A revised version for use with general populations. Journal of Applied Social Psychology, 15, 687699. doi:10.1111/j.1559-1816.1985.tb02268.x

Schneider, S. M. (2012). Income inequality and its consequences for life satisfaction: What role do social cognitions play?. Social Indicators Research, 106, 419-438. doi: $\underline{10.1007 / \mathrm{s} 11205-011-9816-7}$

Solak, N., Jost, J. T., Sümer, N., \& Clore, G. L. (2012). Rage against the machine: The case for system-level emotions. Social and Personality Psychology Compass, 6, 674-690. doi:10.1111/j.1751-9004.2012.00456.x 
Vanneman, R. D., \& Pettigrew, T. F. (1972). Race and relative deprivation in the urban United States. Race, 13, 461-486. doi:10.1177/030639687201300404

Walasek, L., \& Brown, G. D. (2015). Income inequality and status seeking: Searching for positional goods in unequal US states. Psychological Science, 26, 527-533. doi: $\underline{10.1177 / 0956797614567511}$

Wilkinson, R., \& Pickett, K. (2009). Desigualdad. Un análisis de la (in)felicidad colectiva. Madrid: Turner Publicaciones.

Wilkinson, R., \& Pickett, K. (2017). The enemy between us: The psychological and social costs of inequality. European Journal of Social Psychology, 47, 11-24. doi:10.1002/ejsp.2275

Willis, G. B., Carretero-Dios, H., Rodríguez-Bailón, R. \& Petkanopoulou, K. (2016). Versión española de la Escala de Sensación de Poder General. Revista de Psicología Social, 31, 570-587. doi:10.1080/02134748.2016.1190131 
Appendix 1. Spanish version of the Status Anxiety Scale

Apéndice 1. Versión española de la Escala de Ansiedad por el Estatus.

1. Me preocupa que mi posición social actual sea demasiado baja.

2. Me preocupa mucho no ser capaz de alcanzar mis metas académicas o profesionales.

3. Me preocupa que mi estatus social no vaya a mejorar.

4. Me preocupa que mi posición social baje.

5. Siento ansiedad al pensar que me voy a quedar estancado/a en mi posición social toda la vida. 